\title{
The Distribution and Detection of Grapevine red blotch virus in its Host Depend on Time of Sampling and Tissue Type
}

Felicia J. Setiono and Debotri Chatterjee, Plant Pathology and Plant-Microbe Biology Section, School of Integrative Plant Science, Cornell University, Ithaca, NY, 14853, USA; Marc Fuchs, Plant Pathology and Plant-Microbe Biology Section, School of Integrative Plant Science, Cornell University, New York State Agricultural Experiment Station, Geneva 14456, USA; and Keith L. Perry and Jeremy R. Thompson, ${ }^{\dagger}$ Plant Pathology and Plant-Microbe Biology Section, School of Integrative Plant Science, Cornell University

\begin{abstract}
Grapevine red blotch virus (GRBV) is the causal agent of grapevine red blotch, an emerging disease that affects cultivated grapevine such as Vitis vinifera. The ability to detect viruses in grapevine is often hindered by low virus titers compounded by a variable distribution in the plant and seasonal variations. In order to examine these two variables in relation to GRBV, we developed a quantitative polymerase chain reaction (qPCR) method that incorporates both internal and external references to enhance assay robustness. In greenhouse-grown vines infected with GRBV, qPCR identified highest virus titers in

the petioles of fully expanded leaves and significantly reduced levels of virus in the shoot extremities. In vineyard-grown vines infected with GRBV, the virus titer in July and October 2016 followed a pattern similar to that found for the greenhouse-grown plants but, most strikingly, close to half (44\%) of the samples analyzed in June 2015 tested negative for infection. The technique presented and results obtained highlight the variability of virus distribution in its host and provide a useful guide for selecting the best tissues for optimal GRBV diagnosis.
\end{abstract}

Grapevine red blotch virus (GRBV; genus Grablovirus, family Geminiviridae) is the causal agent of a condition in grapevine (Vitis spp.) which can cause significant alterations in the host's metabolism, disrupting normal vegetative growth and berry development (Blanco-Ulate et al. 2017; Sudarshana et al. 2015; Yepes et al. 2018). Disease symptoms were first described in 2008 in California (Calvi 2011), and the first complete sequence of GRBV was obtained 4 years later from Vitis vinifera (Al Rwahnih et al. 2013; Krenz et al. 2012). GRBV has been detected in vines across the United States and Canada (Poojari et al. 2017; Sudarshana et al. 2015), and was recently found in white-berried $V$. vinifera in South Korea (Lim et al. 2016) and in an experimental grapevine collection in Switzerland (Reynard et al. 2018). Despite its relatively recent discovery, GRBV has been detected in archival samples from California collected in 1940 (Al Rwahnih et al. 2015), indicating a longer presence in production vineyards than its initial discovery in 2011 might suggest. Additionally, the identification of GRBV in wild vines (Perry et al. 2016) allows for speculation on both the virus's origins and epidemiology.

The epidemiology of GRBV is still poorly understood. The threecornered alfalfa treehopper, Spissistilus festinus (Hemiptera: Membracidae), has now been implicated in its transmission (Bahder et al. 2016). S. festinus, and species of the genus Spissistilus, occur throughout the United States, Canada, the Caribbean, Central America, and some South American countries (Godoy et al. 2006).

${ }^{\dagger}$ Corresponding author: Jeremy R. Thompson; E-mail: jrt36@cornell.edu

Funding: This work was supported, in part, by the California Grape Rootstock Research Foundation, the California Grape Rootstock Improvement Commission, the American Vineyard Foundation, the California Department of Food and Agriculture, the New York Grape and Wine Foundation, United States Department of Agriculture-National Institute of Food and Agriculture (USDA-NIFA) Critical Agriculture Research and Extension award 201567028-23512, USDA-NIFA Hatch project number 1004285, and the College of Agriculture and Life Sciences, Cornell University.

*The $\boldsymbol{e}$-Xtra logo stands for "electronic extra" and indicates that one supplementary table and five supplementary figures are published online.

Accepted for publication 25 May 2018.

(c) 2018 The American Phytopathological Society
A recent epidemiological study of a GRBV-infected California vineyard revealed an annual spread of 1 to $2 \%$, with a spatiotemporal pattern atypical of that of other grapevine viruses vectored by mealybugs or nematodes (Cieniewicz et al. 2017, 2018). Examples of S. festinus were found in the vineyard along with insects from three other genera, of which specimens consistently tested positive for GRBV by polymerase chain reaction (PCR) over two consecutive years (Cieniewicz et al. 2018).

Many molecular techniques used in diagnostic laboratories today are highly sensitive and allow for the detection of viruses prior to the onset of symptoms. However, due to tissue tropism in its host, the distribution of a virus in infected plants is likely to vary over time. In chronic infections like those of viruses in grapevine, there is also a seasonal variation in symptom expression and virus titer (Čepin et al. 2010; Maree et al. 2013). Therefore, regardless of the sensitivity of the detection method employed, without the correct sampling strategy, the efficacy of any diagnostic approach will be compromised.

For the last 6 years, our research into GRBV has shown that this virus can sometimes elude detection by standard molecular methods such as a multiplex PCR (Krenz et al. 2014): samples taken from plants known to be infected with the virus are negative in diagnostic assays. We hypothesized that this observation was due to spatiotemporal fluctuations in virus titer. To test this idea, and to better understand the optimal sampling strategy, we developed a quantitative (q) PCR method for the detection and quantification of GRBV, tested its efficacy on greenhouse-grown vines, and then applied it on fieldgrown commercial vines at three different time points. The results obtained highlight the variability of virus distribution in its host and provide a useful guide for selecting the best tissues for the optimization of GRBV diagnostic assays.

\section{Materials and Methods}

Plant samples. Plant tissues were sampled from $V$. vinifera 'Cabernet franc' grown in greenhouse conditions consisting of a photoperiod of $16 \mathrm{~h}$ or light and $8 \mathrm{~h}$ of darkness per day at $22 \pm 3^{\circ} \mathrm{C}$. Tissues collected included mature expanded leaves from the basal and middle part of the shoot, petioles of the respective leaves, and emerging leaves (1 to $3 \mathrm{~cm}$ in length). During fall 2014 and 2015, tissues were taken from GRBV-infected grapevine clones GV30, GV31, and GV32, all of which were propagated from the same mother $V$. vinifera 'Cabernet franc' vine NY358, infected with the GRBV strain JRT[456]17NOV10 (accession number JQ901105). Symptoms 
associated with GRBV were usually only observed in the older leaves. For the temporal study, four field-grown grapevines (R18V1, R18V19, R20V3, and R20V9) of V. vinifera 'Cabernet franc' from a commercial California vineyard (established in 2008 in Napa County, CA, USA) were selected for sampling in mid-June 2015 and mid-July and midOctober 2016. These four vines were selected based on their previously testing positive for GRBV using a multiplex PCR method (Krenz et al. 2014). Three shoots of approximately $1.5 \mathrm{~m}$ in length per plant were collected and, for each vine, seven leaf and petiole samples were excised (Fig. 1). Symptoms associated with GRBV were only observed in the older leaves of those vines harvested in October 2016 and not in any other tissue type or sampling time. Within 12 to $24 \mathrm{~h}$ after harvesting, all tissue samples were carefully excised with a clean razor blade, weighed $(100 \mathrm{mg})$, inserted into a $1.5-\mathrm{ml}$ microcentrifuge tube, and snap frozen in liquid nitrogen and stored at $-80^{\circ} \mathrm{C}$ until total nucleic acid (TNA) extraction. Healthy grapevine from the $V$. vinifera 'Cabernet franc' clone TJB1-1 was used for all negative plant controls. Each sample was a composite of three pieces of tissue selected by eye as evenly distributed across the designated area (Fig. 1). For the leaf tissue, this meant taking one excision close to the midrib and one on either side. Base and top samples were located in the lower and upper third of the leaves, respectively. For petiole samples, three equal excisions were made along the organ.

TNA extraction. TNA extraction from grapevine tissue was modified from the cetyltrimethylammonium bromide (CTAB)based protocol described by Gambino et al. (2008). Plant tissue (100-mg individual samples) was ground in liquid nitrogen using a mortar and pestle. Extraction buffer $(500 \mu \mathrm{l}$ of $2 \%$ CTAB, $2.5 \%$ PVP-40, $2 \mathrm{M} \mathrm{NaCl}, 100 \mathrm{mM}$ Tris- $\mathrm{HCl}$ [pH 8.0], and $24 \mathrm{mM}$ EDTA [pH 8.0]) preheated to $65^{\circ} \mathrm{C}$ was added to the mortar to form a homogenate that was rapidly transferred to a microcentrifuge tube containing $10 \mu \mathrm{l}$ of $\beta$-mercaptoethanol. The homogenate was incubated with mixing (at $750 \mathrm{rpm}$ ) at $60^{\circ} \mathrm{C}$ for $1 \mathrm{~h}$. An equal volume of chloroform-isoamyl alcohol $(24: 1$ [vol/vol]) was added before vortexing vigorously until an emulsion formed. The emulsion was centrifuged at $11,000 \times g$ for $10 \mathrm{~min}$ at $4{ }^{\circ} \mathrm{C}$. The supernatant was transferred to a clean microcentrifuge tube and 0.7 volume of icecold isopropanol was added and mixed before centrifuging at $13,000 \times g$ for $15 \mathrm{~min}$ at $4^{\circ} \mathrm{C}$. The liquid was discarded and the resulting pellet was washed with $70 \%$ ethanol by centrifuging for another $2 \mathrm{~min}$. The tube was then inverted to air dry and the pellet was resuspended in $50 \mu \mathrm{l}$ of RNase-free water. The quantity and quality of TNA extracted was estimated both spectrophotometrically (NanoVue Plus Spectrophotometer; GE Healthcare) and visually by electrophoresis on a $1 \%$ agarose gel stained with ethidium bromide in $0.5 \times$ Tris-acetate buffer. Samples with $260 / 280 \mathrm{~nm}$ or $260 / 230 \mathrm{~nm}$ ratios outside of the range $2 \pm 0.5$ were discarded, as were samples with clear signs of RNA degradation as determined by the absence of visible $28 \mathrm{~S}$ and $18 \mathrm{~S}$ fragments when separated by gel electrophoresis.

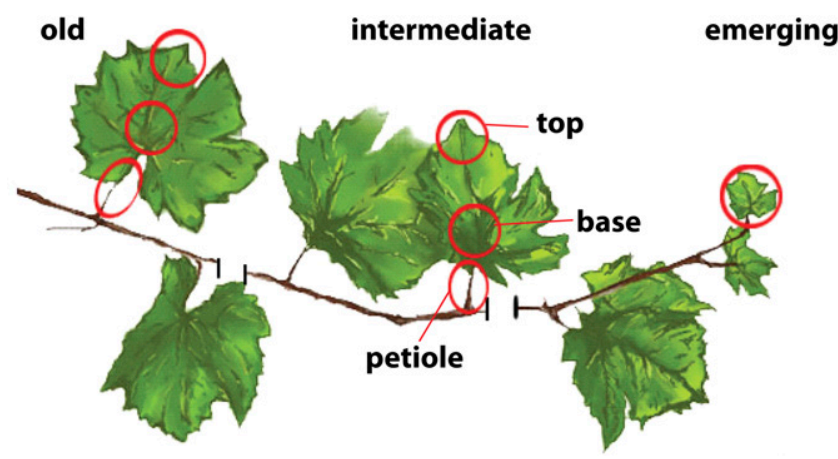

Fig. 1. Relative positions along a grapevine shoot that were sampled for total nucleic acid extraction. Circles indicate the parts of the shoot that were excised and extracted. Two samples were taken from seven locations (circle) on each shoot; namely, old leaf (1) petioles (1pet), basal (1bas), and top part (1top); intermediate leaf (2) petioles (2pet), basal (2bas), and top part (2top); and emerging leaf (3eme), entire leaf.
For qPCR, the concentration of all TNA samples was normalized to $50 \mathrm{ng} / \mu \mathrm{l}$. All TNA samples, original and normalized, were then stored at $-20^{\circ} \mathrm{C}$.

Primer design, selection, and validation. Virus-specific and internal control primers were designed using the PrimerQuest tool from Integrated DNA Technologies (http://www.idtdna.com/Primerquest/ Home/Index) with default settings; these included optimal parameters of melting temperature $\mathrm{T}_{\mathrm{m}} 62^{\circ} \mathrm{C}, \mathrm{G}+\mathrm{C}$ content $50 \%$, primer size of 22 nucleotides (nt), and an amplicon size of approximately $100 \mathrm{nt}$. Virus-specific primer sequences were initially based on the sequence of GRBV isolate NY358 (GenBank accession JQ901105) and later adapted to align with all known GRBV sequences (Supplementary Fig. S1). In selecting for the best primer pairs and combinations, all primer pairs (Table 1) were initially screened by conventional PCR with cycling conditions of $5 \mathrm{~min}$ at $95^{\circ} \mathrm{C}$ (1 time) followed by $30 \mathrm{~s}$ at $95^{\circ} \mathrm{C}$ and $30 \mathrm{~s}$ at $60^{\circ} \mathrm{C}$ ( 40 times) using plant TNA from GRBV-infected and uninfected plants as templates. PCR products were separated on a $1 \%$ agarose gel by electrophoresis in $0.5 \times$ Tris-acetate buffer and only those primers giving unique PCR products of the expected size without any visible nonspecific amplification (Supplementary Fig. S2) were used in the subsequent validation experiments.

qPCR. Each $25-\mu 1$ qPCR contained $12.5 \mu$ l of PerfeCTa SYBR Green FastMix plusROX (Quanta Biosciences), $10.5 \mu$ l of $\mathrm{H}_{2} \mathrm{O}$, $0.5 \mu \mathrm{l}$ of $10 \mu \mathrm{M}$ forward primer, $0.5 \mu \mathrm{l}$ of $10 \mu \mathrm{M}$ reverse primer, and $1 \mu \mathrm{l}(50 \mathrm{ng})$ of template TNA. All reactions were run in duplicate in a thermocycler (ABI 7000 Sequence Detection System; Applied Biosystems), with cycling conditions of $5 \mathrm{~min}$ at $95^{\circ} \mathrm{C}$ (1 time) followed by $30 \mathrm{~s}$ at $95^{\circ} \mathrm{C}$ and $30 \mathrm{~s}$ at $60^{\circ} \mathrm{C}$ (40 times). Threshold cycle number $\left(\mathrm{C}_{\mathrm{T}}\right)$ values were set automatically by the ABI PRISM 7000 Sequence Detection System software V1.2x (Applied Biosystems 2004). All samples were run in duplicate for both virus-specific and internal control primers. Negative nontemplate controls (NTC) included TNA extracted from GRBV-free grapevine TJB1-1 and RNase-free water. Positive controls included a dilution series of a known GRBV template (details below). $\mathrm{C}_{\mathrm{T}}$ values were exported and their averages and standard deviations were calculated. To compare the sensitivity of the qPCR method with conventional multiplex PCR (Krenz et al. 2014), serial dilutions $\left(1 \times 10^{-1}\right.$ to $\left.1 \times 10^{-8}\right)$ of TNA extracted from GRBV-positive leaf tissue from plant GV32 and TNA extracted from GRBV-negative leaf tissue from plant TJB1-1 were made, aliquoted, and frozen for single use. These dilutions were then used as templates in either the qPCR assay developed here or conventional multiplex PCR as described by Krenz et al. (2014). Two methods of quantitation were applied to all greenhouseand field-grown material: (i) relative, using an internal reference derived from the qPCR results for the internal control primers, and (ii) absolute, using an external reference derived from the qPCR results of a dilution series of a known GRBV template. All reactions were prepared manually in a laminar flow hood on ice in a laboratory where no target amplicons were handled.

Relative quantitation: Internal reference. The $\Delta \Delta \mathrm{C}_{\mathrm{T}}$ method was used to calculate the fold difference of virus DNA between two samples (Yuan et al. 2006). First, the differences between the average $\mathrm{C}_{\mathrm{T}}$ values $\left(\Delta \mathrm{C}_{\mathrm{T}}\right)$ obtained from PCR using virus-specific and internal control for each TNA sample were calculated. $\Delta \Delta \mathrm{C}_{\mathrm{T}}$ was then calculated by subtracting $\Delta \mathrm{C}_{\mathrm{T}}$ of sample $\mathrm{B}$ from $\Delta \mathrm{C}_{\mathrm{T}}$ of sample $\mathrm{A}$, where samples $\mathrm{A}$ and $\mathrm{B}$ refer to an individually extracted TNA samples from a specific tissue and plant. The fold difference was calculated using the formula $2^{-\Delta \Delta C T}$. This value indicates the amount of target sequence found in sample A relative to sample B.

Absolute quantification: External reference. TNA from GRBVinfected material (NY358) was used as a template for rolling circle amplification using the TempliPhi amplification kit (GE Healthcare), as described by the manufacturer. The amplification products were digested by Pst (New England Biolabs) and separated by agarose gel electrophoresis. The virus-specific fragment of $3.2 \mathrm{~kb}$ was excised from the gel using the Zymoclean Gel DNA Recovery Kit (Zymo Research) and cloned into pUC19 linearized by PstI. The resulting plasmid was propagated in Escherichia coli cells (DH5 $\alpha)$ 
and purified using the EZNA plasmid midi kit (Omega). The concentration of the resulting pUC19MLV1.0 plasmid was determined spectrophotometrically (NanoVue Plus; GE Healthcare) and serial dilutions of $6 \mathrm{ng} / \mathrm{ul}, 60 \mathrm{pg} / \mu \mathrm{l}, 600 \mathrm{fg} / \mu \mathrm{l}, 6 \mathrm{fg} / \mu \mathrm{l}$, and $60 \mathrm{ag} / \mu \mathrm{lmade}$, aliquoted, and stored for single use at $-20^{\circ} \mathrm{C}$.

Average and standard deviation of $\mathrm{C}_{\mathrm{T}}$ values for plasmid-derived GRBV DNA were used for absolute quantification of GRBV DNA found in extracted TNA samples. Regression analysis was done for $\mathrm{C}_{\mathrm{T}}$ values against the $\log$ amount of copies of GRBV plasmid input in the qPCR. The line of best fit was generated for $\mathrm{C}_{\mathrm{T}}$ and the $\log$ amount of GRBV DNA. The equation generated for the line of best fit was used to calculate the absolute amount of the virus found in each sample.

$\mathrm{C}_{\mathrm{T}}$ values corresponding to extracted TNA of all GRBV-free grapevine TJB1-1 samples (plant NTC) across all qPCR assays were also recorded. The 95 th percentile of these $C_{T}$ values (and its corresponding virus copy number, as calculated by regression analysis) was defined as the cut-off between positive and negative.

Statistical analysis. A mixed-effect model was used to analyze differences between the amounts of virus in different tissue types, taking into account the random effects potentially given by different plants, different canes within a plant, and different leaf developmental stages within each cane (i.e., old leaves and intermediate leaves). The mixed-effect model is used when differences in fixed variables are potentially affected by sources of variations from one or more random variables (Piepho et al. 2003). The model also produces a more robust analysis when sample size is small, variances are unequal, or unbalanced designs of data are present. Tukey's honestly significant difference (HSD) tests were done to evaluate significance in differences of virus concentrations between the tissue types. The significance level was set at $\alpha=0.05$. Model analysis was done in JMP 12 Pro statistical software (SAS Institute Inc.).

\section{Results}

Primer selection and $q P C R$ validation. In order to evaluate different primer pairs for their performance, seven twofold dilutions in sterile water of TNA from GRBV-infected tissue served as templates for qPCR. For all dilutions, $\mathrm{C}_{\mathrm{T}}$ duplicate values had standard deviations of less than 0.3 . The differences between the $C_{T}$ values $\left(\Delta C_{T}\right)$ of virus-specific and internal control reactions for each TNA dilution were calculated. Regression analysis was done for $\Delta \mathrm{C}_{\mathrm{T}}$ against the $\log$ amount of TNA input and the line of best fit was generated for $\Delta \mathbf{C}_{\mathrm{T}}$. A slope of $<0.1$ was set as the acceptable threshold for equally efficient primer pairs, as recommended by the thermocycler manufacturer (Applied Biosystems). $\Delta \mathrm{C}_{\mathrm{T}}$ variations corresponding to changes in TNA from GRBV-infected tissue were plotted on a semilogarithmic graph against log values of TNA input (Supplementary Fig. S3). The characteristics of the line of best fit for each of the semilogarithmic graphs and slopes of the lines are summarized in Supplementary Table S1. Based on a slope of $<0.1$ as the acceptable threshold, the combination of primer pairs $(3 \mathrm{v} / 4 \mathrm{v}$ for GRBV and $7 \mathrm{i} / 8 \mathrm{i}$ for NADP+) was selected for all further assays. In addition, PCR amplification efficiencies (E) were calculated based on the slope $(m)$ of $\Delta \mathrm{C}_{\mathrm{T}}$ value against the log amount of TNA input using equation $\mathrm{E}=10-1 / m-1$ (Yuan et al. 2006). The primer combinations of $3 \mathrm{v} / 4 \mathrm{v}$ and $7 \mathrm{i} / 8 \mathrm{i}$ have PCR amplification percent efficiencies of 92.4 and 97.0, respectively (Bustin et al. 2009; Schmittgen and Livak 2008).

GRBV distribution in greenhouse-grown grapevines varies according to tissue type. Tissues from greenhouse-grown plants were collected from shoots of plants GV30 $(n=3), \operatorname{GV} 31(n=3)$, and GV32 $(n=4)$ for a total of 10 potted vine samples; each of these plants was clonally propagated in 2012 from the same original Cabernet franc mother vine NY358. In all, seven tissue types were analyzed as depicted in Figure 1: 1pet, 1bas, 1top, 2pet, 2bas, 2top, and 3eme. First virus copy number for each sample $(n=70)$ was calculated using regression analysis of the external references. The mixed-effect model revealed that there were no significant differences in viral concentration between petiole (1pet +2 pet $[n=20])$, base $(1$ bas +2 bas $[n=20])$, and top part (1top +2 top $[n=20])$ of a leaf in greenhousegrown plants. However, the Tukey's HSD test revealed that there was a significant difference between amounts of GRBV in the petiole of intermediate leaves (2pet $[n=10])$ compared with that in the top part of their associated leaves (2top $[n=10])(P=0.0368)$. However, there was no such difference between the petioles and either associated leaf sample (base or top) obtained for old leaves (Fig. 2A).

Virus copy numbers in old and intermediate leaves were obtained by averaging the combined data for petioles and the corresponding base and top part of the leaves (1pet +1 bas +1 top $[n=30]$ versus 2 pet +2 bas +2 top $[n=30]$ versus 3eme $[n=10])$. After taking into account the potential random effects from different plants and vines, Tukey's HSD tests revealed that the virus amounts in old leaves versus emerging leaves as well as in intermediate leaves versus emerging leaves are significantly different $(P=0.0017$ and $P=0.0253$, respectively). These results were further supported by relative quantification after normalization to the internal reference using the $2^{-\Delta \Delta C T}$ method, where amounts of GRBV in the petioles ranged from 23 (intermediate petiole) to 119 (old petiole) times that found in the emerging leaves (Fig. 2B).

Variation in GRBV titer in field grapevines depends on time of sampling and tissue-type. The virus concentration in different tissues of four field-grown $V$. vinifera 'Cabernet franc' vines was assessed at three time points. In total, 12 shoots were used as a source of TNA (four vines, 3 shoots per vine) at three sampling times: June 2015, July 2016, and October 2016. Sampling in 2015 was initially done to make a comparison between the testing of field-collected and greenhouse-grown vines. Testing in 2016 was done to compare results obtained when testing the same vines early and late in the same season. Absolute and relative virus amounts are shown in Figure 3. There are distinct differences in virus titer for each sampling, a general trend being a gradual increase in total viral copy number and a more even distribution in all tissues with time. Average virus copy number $\left(\log _{10}\right)$ per sample was 2.6 (standard error $\left.[\mathrm{SE}]=0.4\right), 9.7$ $(\mathrm{SE}=0.1)$, and $10.4(\mathrm{SE}=0.1)$ for June 2015, July 2016, and October 2016, respectively.

The greatest degree of variation across different tissue types was detected in the June 2015 samples. A mixed-effect model was used to test for significance in differences of virus amount between

Table 1. Primers tested for use in quantitative polymerase chain reaction of Grapevine red blotch virus (GRBV)

\begin{tabular}{llcccc}
\hline Primer & \multicolumn{1}{c}{ Sequence } & Size $(\mathbf{b p})^{\mathbf{a}}$ & Target gene & GenBank accession number & Sequence location \\
\hline $1 \mathrm{v}$ & GTACCGWRYTCGACGGTATCYC & 105 & GRBV Rep & JQ901105.2 & $2,710-2,731$ \\
$2 \mathrm{v}$ & CACCATATCGTCTCAYTCCTAYC & $\ldots$ & $\ldots$ & $\ldots$ & $2,814-2,792$ \\
$3 \mathrm{v}$ & ACATCTCTGGGYTTKGTGATATT & 113 & GRBV Rep & $\ldots$ & $2,764-2,786$ \\
$4 \mathrm{v}$ & CTACACGCCTTGCTCATCTT & $\ldots$ & $\ldots$ & $\ldots$ & $2,876-2,857$ \\
$5 \mathrm{i}$ & CACCATGAGTCTTTGGTAGAGG & 119 & eEF1a1 & NC_012014 & $13,422,791-13,422,812$ \\
$6 \mathrm{i}$ & GCAGGATCATCTTTGGAGTTAGA & $\ldots$ & $\ldots$ & $\ldots$ & $13,422,909-13,422,887$ \\
$7 \mathrm{i}$ & GGTGTTGGTGTCTCCATAGTT & 110 & NADP+ & NC_012010 & $5,401,243-5,401,263$ \\
$8 \mathrm{i}$ & CCTAGTTGCCTTGAGGTCTTT & $\ldots$ & $\ldots$ & $\ldots$ & $5,401,352-5,401,332$ \\
$9 \mathrm{i}$ & GTAGAAGGTGTGATGCCAGATT & 102 & Actin & NC_012014 & $20,251,517-20,251,538$ \\
$10 \mathrm{i}$ & GGCACAATCCAAGAGAGGTATT & $\ldots$ & $\ldots$ & $\ldots$ & $20,251,619-20,251,598$ \\
\hline
\end{tabular}

${ }^{a}$ Expected size in base pairs of amplicon generated by primer pairs. 
different tissue types from expanded leaves (petiole, basal, and top part of a leaf, excluding emerging leaf), while taking into account random effects due to differences in plants, shoots, and leaf developmental stages (old leaf versus intermediate leaf). The model revealed that differences in virus amount between tissue types are significant $(P=$ 0.0061 ), and that those differences are principally due to differences between the petioles versus the top parts of the leaves $(P=0.0051)$. Dissecting this observation further showed that this significant difference was because of differences between the petiole and the top part of leaves in old leaves $(P=0.005)$ but not in intermediate leaves. On the other hand, for July 2016, Tukey's HSD tests showed that there were significant differences in virus concentration between all pairs of tissue types (petiole versus base $P=0.015$, petiole versus top $P<$ 0.0001 , and base versus top $P=0.0004)$. Equally for October 2016, differences between all pair of tissue types were significant $(P<0.0001)$.
Differences between the expanded leaves and emerging leaves were most notable in the 2015 samples when compared with the two 2016 samplings, although the emerging leaf consistently carried less virus than other tissue types. Tukey's HSD tests revealed that there were significant differences in the virus amount between June 2015 old and intermediate leaves versus emerging leaves $(P<0.0001$ and $P=0.0014$, respectively). Similarly, in both 2016 samplings, there were significant differences between emerging leaves versus old leaves and between emerging leaves versus intermediate leaves (all $P<0.0004$ ).

The younger the leaf of a GRBV-infected plant, the more likely it is to test negative. Based on a $C_{T}$ value cut-off of 31.1 , calculated as described above in methods as the 95th upper percentile of all plant NTC, the infection status and viral copy number for all samples from both greenhouse- and field-grown samples were calculated. The

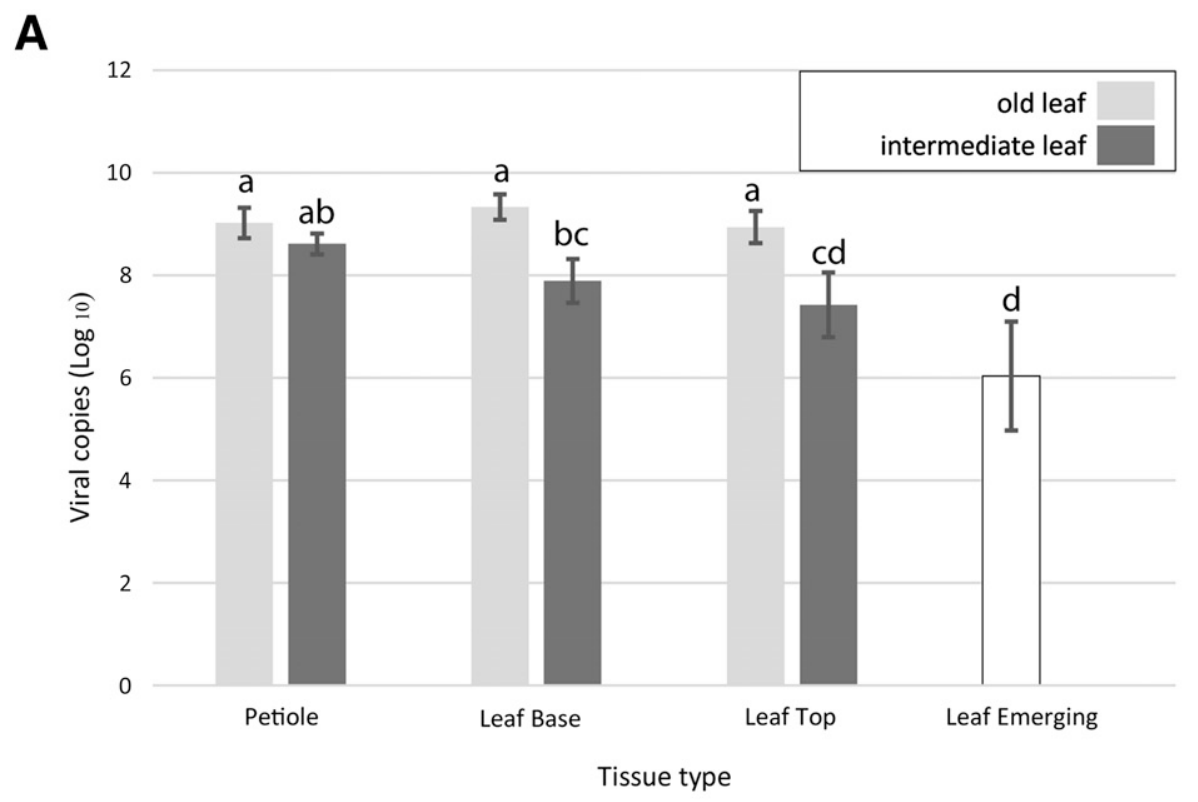

B

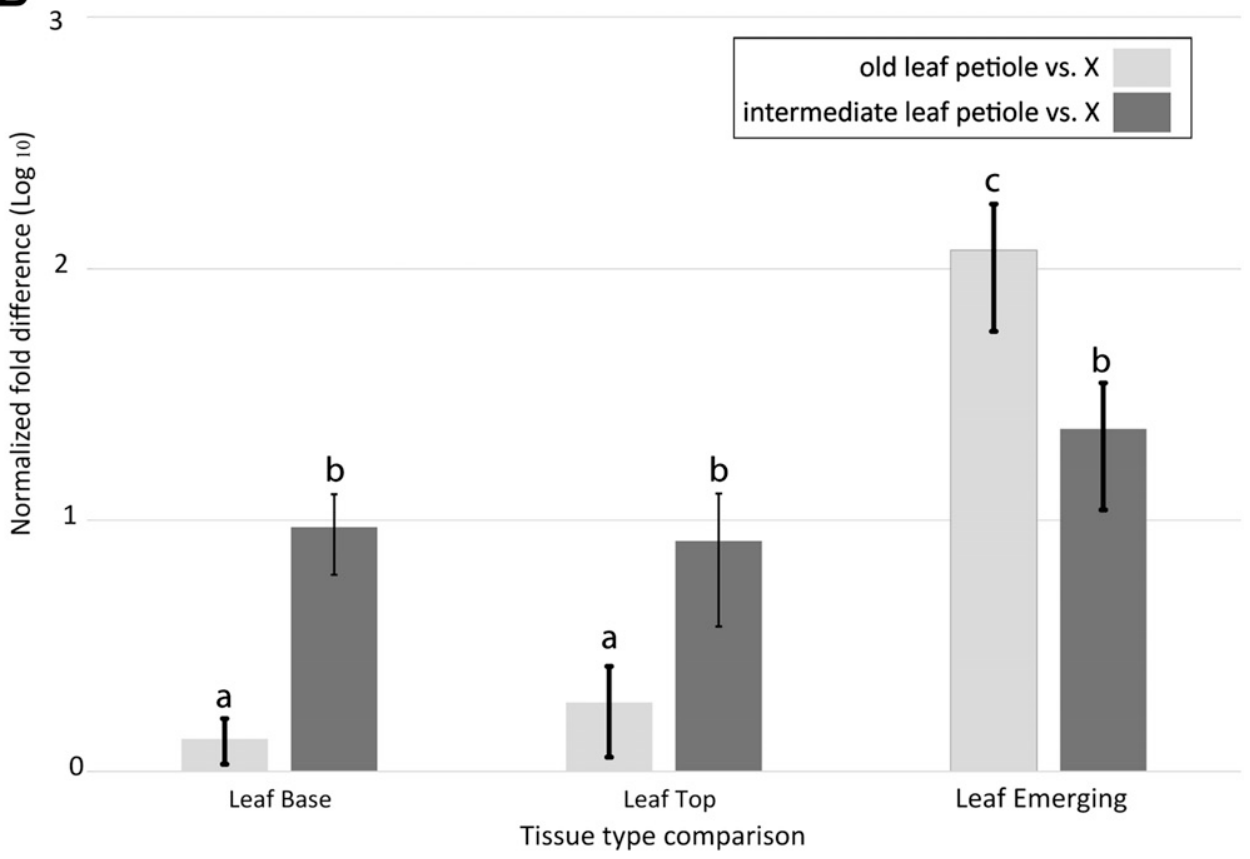

Fig. 2. Absolute and relative distribution of Grapevine red blotch virus (GRBV) in greenhouse-grown vines. A, Histogram (absolute) of the average log number of viral copies in extracted total nucleic acid of different tissue types in 10 shoots. Light gray bars indicate viral copies found in old leaves, dark gray bars indicate those found in intermediate leaves, and the white bar indicates those found in emerging leaves. Error bars show standard error of the mean. B, Histogram (relative) showing the fold difference of GRBV amount in petiole of either old or intermediate leaves versus the other types of tissues tested. Vertical axes are set on logarithmic scales. Error bars indicate standard error of the mean. 
results for the greenhouse- and field-grown samples of June 2015 are shown in Table 2 and Supplementary Figure S4. Many of the 2015 field-grown samples have lower virus titers compared with the greenhouse-grown samples; a much higher percentage (44.0 versus $11.0 \%$, respectively) of samples from field-grown plants tested negative for GRBV. Notably, samples that scored negative for virus infection were more often taken from younger leaves (intermediate and emerging; $75.7 \%$ ) versus old leaves $(24.3 \%)$.

\section{Discussion}

In this work, we set out to test the hypothesis that samples obtained from GRBV-infected vines that tested negative in our conventional
PCR assay (Krenz et al. 2014) did so because of variation in distribution of the virus in its host. We began by developing and validating a qPCR method to quantitatively detect viral DNA using two references for quantification; an internal host gene (relative reference) and a dilution series of an external cloned virus sequence of known concentration (absolute reference). Our template in the reaction was extracted TNA rather than DNA alone, because we found enriching for DNA (single-stranded and double-stranded) alone and, therefore, the virus to be less straightforward than including the genomic DNA relative reference during the PCR. Although DNA is the target in our assays, including RNA in the sample was also useful for monitoring the overall quality of the extracts by gel electrophoresis, grapevine

\section{Absolute}

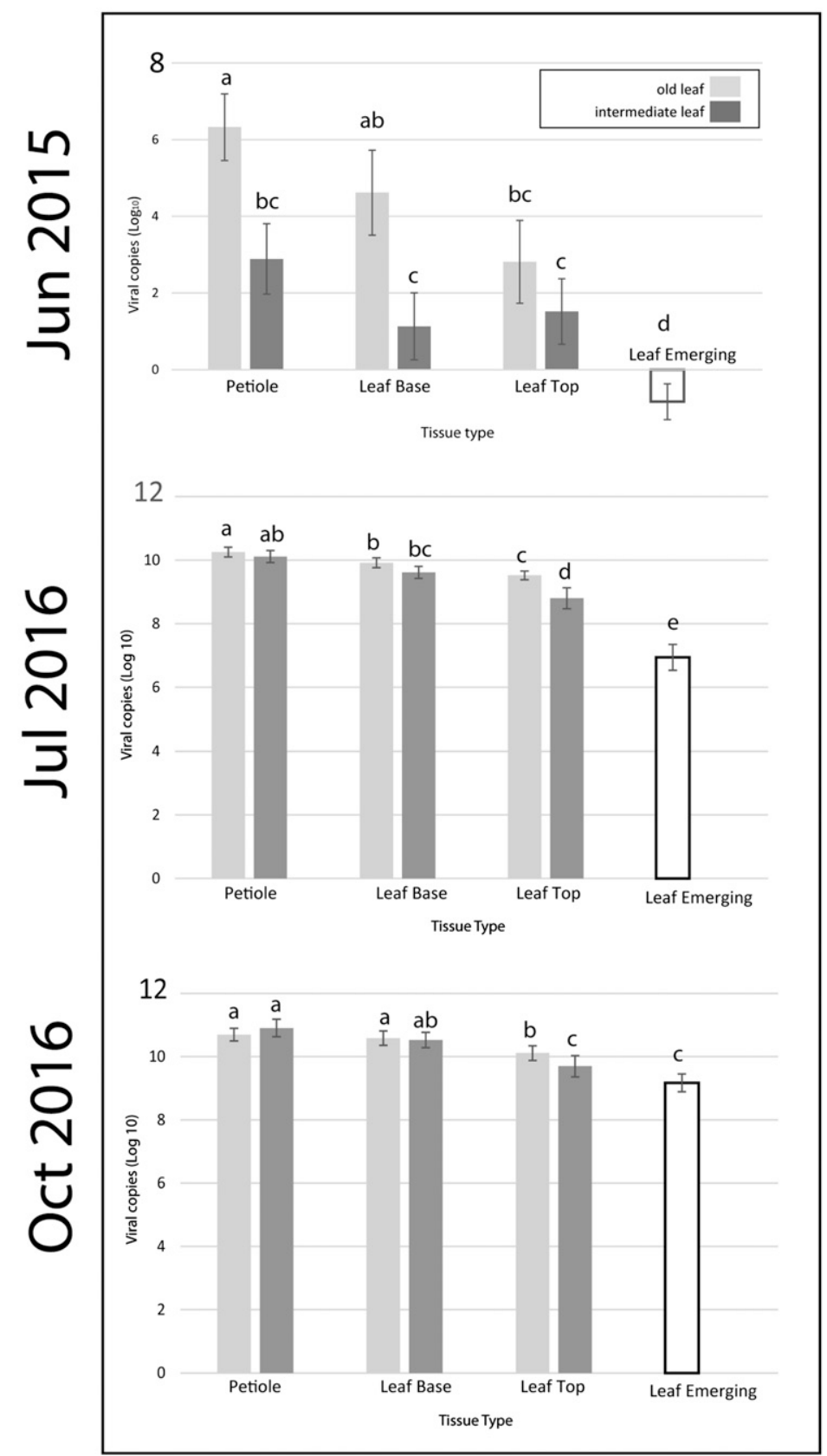

Relative

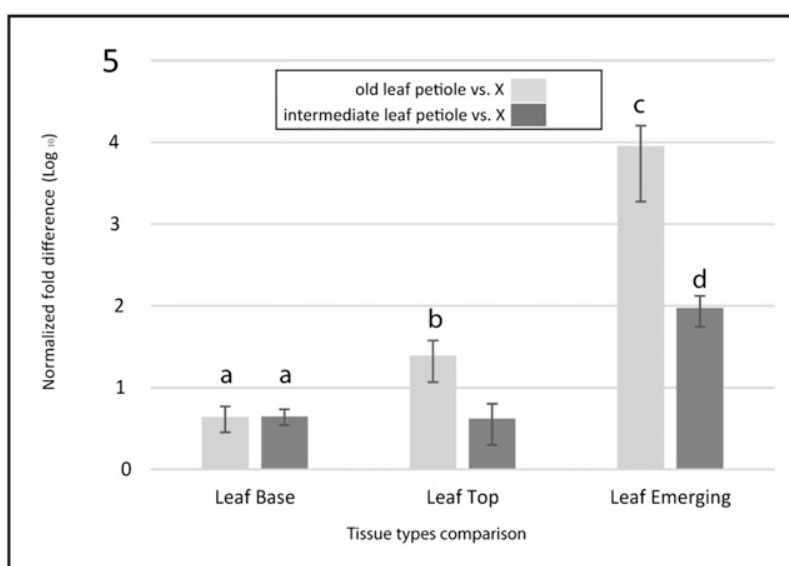

4

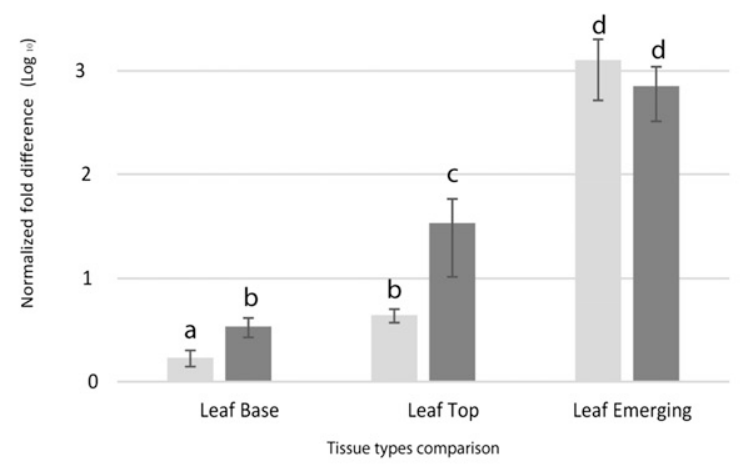

2

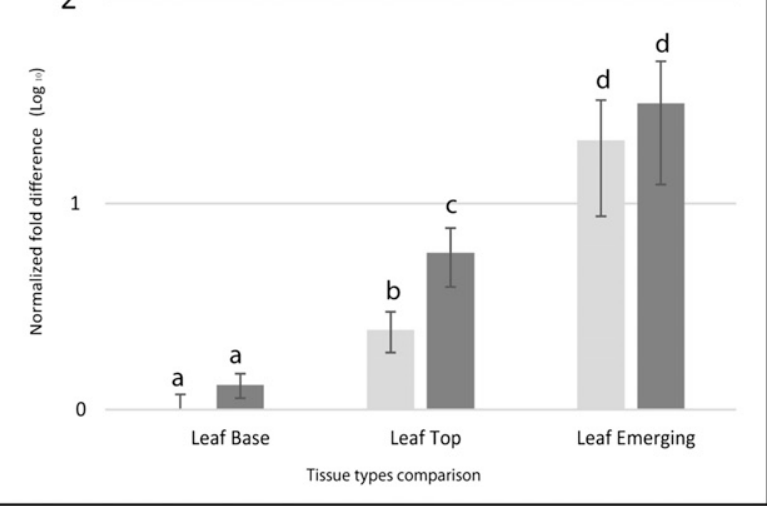

Fig. 3. Histograms showing the mean absolute and relative distribution of Grapevine red blotch virus (GRBV) in four field-grown vines (three shoots per vine) sampled at three different time points. Histograms on the left (absolute) depict the average log number of viral copies in extracted total nucleic acid of different tissue types. Light gray bars indicate viral copies found in old leaves, dark gray bars indicate those found in intermediate leaves, and white bars indicate those found in emerging leaves. Histograms on the right (relative) depict the fold difference of GRBV amount in petioles of either old or intermediate leaves versus the other types of tissues tested. Vertical axes are set on logarithmic scales. Error bars show standard error of the mean. 
being notoriously recalcitrant to nucleic acid extraction (Gambino et al. 2008). RNA integrity provides an indirect indicator of TNA quality. Incorporation of the internal host gene control into this assay should specifically compensate for potential inhibitors of qPCR when interpreting virus titers.

The qPCR components and parameters were initially tested according to published parameters (Bustin et al. 2009) and validated against a sample known to be positive for GRBV. This testing then extended to analyzing different tissue types. Our choice of tissue type was based on accessibility from a sampling perspective, leaves and their petioles being easier to sample than cane, trunk, or root. Though not included in this study, the testing of dormant canes has, in our hands, provided very consistent and reliable results. Greenhousereared vines revealed a distribution of GRBV that initially indicated that petioles are the richest source of virus, while emerging leaves are the poorest, a pattern similar to that reported for the RNA viruses Grapevine leafroll-associated virus 1, -2, and -3 (GLRaV-1, -2, and -3) using enzyme-linked immunosorbent assay (Monis and Bestwick 1996). A reduction in titer in certain strains of GLRaV-3 at the growing tip was also observed using reverse-transcription (RT)-PCR (Chooi et al. 2016). When our assay was then applied to field-grown vines previously reported to be GRBV positive, a comparable trend was observed whereby the older leaf material consistently contained more virus than the younger. These differences were particularly striking in the material sampled in June 2015, in which 44\% (37 of 84 ) of the samples tested negative. A similar (40\%) false-negative rate was obtained for one strain of GLRaV-3 (NZ2) using RTqPCR (Chooi et al. 2016). An RT-PCR assay for the detection of Grapevine rupestris stem pitting-associated virus also tested negative for the virus in buds collected from green shoots during the summer months (Stewart and Nassuth 2001). Subsequent testing in July and October 2016 of tissue from the same GRBV-infected vines produced not a single false negative, with average virus copy numbers for all tissue types increasing to around $1 \times 10^{10}$ per $50 \mathrm{ng}$ of input TNA (Fig. 3). The reason for this is unclear except for a likely difference in the stage of infection for each tested vine, earlier stages having a more variable distribution as the virus gradually colonizes its host, reaching "saturation" at the end of the growing season, as observed for the October 2016 samples. A more extensive analysis of field-grown GRBV-infected samples across a number of growing seasons could test this idea. For GLRaV, in general, titer appears to be at its lowest early in the growing season (April to May) and reaching a peak around dormancy (November to February) although, again, this appears to differ from virus to virus, with GLRaV-4 having the most variable host distribution (Osman et al. 2011). This pattern of virus spread within the plant at the beginning of the growing season also occurred when the spatiotemporal distribution of a single GLRaV-3 isolate was measured in four different $V$. vinifera cultivars (Tsai et al. 2012).

Table 2. Percentages (\%) of samples scored as negative for Grapevine red blotch virus (GRBV) by set cut-off value for all tissues in different leaf types and growing locations (greenhouse- and field-grown, June 2015) ${ }^{\mathrm{a}}$

\begin{tabular}{|c|c|c|c|c|c|c|c|c|}
\hline \multirow[b]{3}{*}{ Location } & \multicolumn{7}{|c|}{ Leaf and tissue types ${ }^{b}$} & \multirow[b]{3}{*}{ All $^{\mathbf{c}}$} \\
\hline & \multicolumn{3}{|c|}{ Old } & \multicolumn{3}{|c|}{ Intermediate } & \multirow[b]{2}{*}{ Emerging } & \\
\hline & Petiole & Base & Top & Petiole & Base & Top & & \\
\hline Greenhous & 0 & 0 & 0 & 0 & 0 & 0 & 11.1 & 1.6 \\
\hline $\begin{array}{l}\text { Field, June } \\
2015\end{array}$ & 8.3 & 25.0 & 41.7 & 33.3 & 58.3 & 50.0 & 91.7 & 44.0 \\
\hline
\end{tabular}

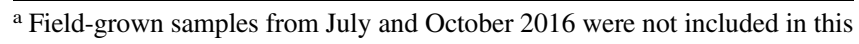
study because none of these samples scored as negative for GRBV. Threshold cycle number $\left(\mathrm{C}_{\mathrm{T}}\right)$ values corresponding to extracted total nucleic acid of all GRBV-free grapevine TJB1-1 samples (nontemplate control) across all quantitative polymerase chain reaction assays were also recorded. The 95th percentile of these $C_{T}$ values (31.1) was defined as the cut-off between positive and negative.

${ }^{\mathrm{b}}$ Leaf types $=$ old, intermediate, and emerging leaves.

c All samples.
RNA viruses dominate the known grapevine virome, and it was not until very recently that the very first grapevine-infecting DNA viruses, including GRBV, were characterized (Al Rwahnih et al. 2013; Krenz et al. 2012; Zhang et al. 2011). In grape and woody plants, too, a number of novel divergent gemini-like viruses have recently been discovered (Al Rwahnih et al. 2017; Basso et al. 2015; Loconsole et al. 2012; Ma et al. 2015). Thus, this present study should not only assist diagnosticians in their selection of the best sampling time and tissue of suspected GRBV-infected grapevine but also more generally provide an interesting insight into the spread of a DNA virus within a woody plant. The qPCR method developed here is comparable in sensitivity with the conventional multiplex PCR previously reported (Krenz et al. 2014) (Fig. 4). The limit in the detection threshold was based on background nonspecific amplification in healthy controls, a factor that, in theory, could be reduced by adopting a TaqMan qPCR approach. Our choice of including both an internal and external reference was made so as to add robustness to the method; regression analyses for both references for all but one of the different collection datasets showed a good correlation $\left(R^{2}>0.7\right)$ (Supplementary Fig. S5).

In conclusion, the work presented here shows that GRBV levels in grapevine can be highly variable, depending on the type of tissue selected and the growth stage of the plant. The use of positive controls from greenhouse-grown plants or stored tissue provides a reliable reference standard for the testing of field plants but the possibility of
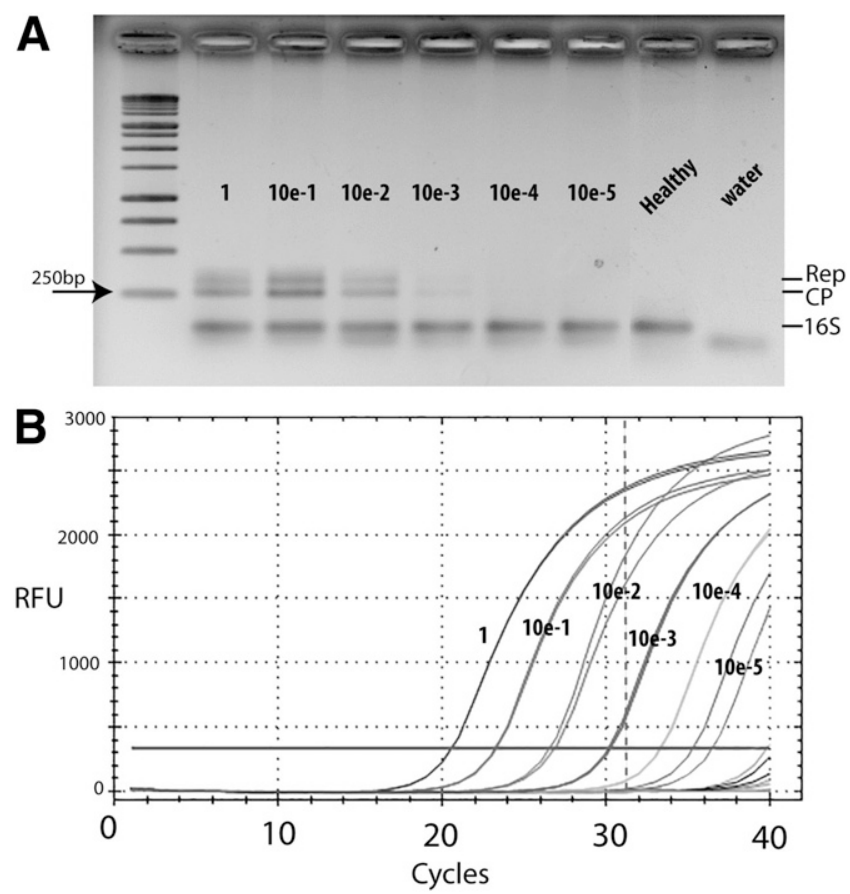

Fig. 4. Sensitivity comparison between the newly described quantitative polymerase chain reaction (qPCR) method and conventional multiplex PCR (Krenz et al. 2014). A, Multiplex PCR products separated on a 1.5\% agarose gel. First lane shows the DNA size marker (Benchtop 1-kb ladder; Promega Corp.) with the fragment of 250 nucleotides marked with an arrow. Lanes 2 to 6 are the PCR products obtained from 10-fold dilutions of Grapevine red blotch virus (GRBV)-infected material in a background of healthy grapevine total nucleic acid extract. Lane 8 shows healthy total nucleic acid extract. Lane 9 shows the water control. Positions of PCR amplicons specific to the viral replicase (Rep), coat protein (CP), and host $16 \mathrm{~S}$ are shown on the right. A primer-dimer-derived fragment smaller than the internal control (16S) can also be seen in some of the samples, including the water control. $B, q P C R$ results using the same 10-fold dilutions of GRBV-infected material in a background of healthy extract; PCR cycle number ( $x$-axis) against relative fluorescence unit (RFU) (y-axis). The threshold for determining the threshold cycle number $\left(C_{T}\right)$ value is depicted by the horizontal line. The cut-off $C_{T}$ of 31.1 , as determined as the 95th percentile of all $C_{T}$ values of healthy grapevine controls used in each assay, is shown by the dotted line. Changes in fluorescence of the GRBV-positive sample dilutions are shown by shaded lines. Gray to black lines are the results of nontemplate water controls. 
false negatives will always be an issue. Our data suggest that the composite sampling of petiole tissue from older leaves at the base of the vine will minimize false negatives in diagnostic assays.

\section{Acknowledgments}

We thank H. McLane, Z. Hyder, and E. Markel for technical support and discussions; and K. Packard from the Cornell University Statistical Consulting Unit.

\section{Literature Cited}

Al Rwahnih, M., Alabi, O. J., Westrick, N. M., Golino, D., and Rowhani, A. 2017. Description of a novel monopartite geminivirus and its defective subviral genome in grapevine. Phytopathology 107:240-251.

Al Rwahnih, M., Dave, A., Anderson, M. M., Rowhani, A., Uyemoto, J. K., and Sudarshana, M. 2013. Association of a DNA virus with grapevines affected by red blotch disease in California. Phytopathology 103:1069-1076.

Al Rwahnih, M., Rowhani, A., and Golino, D. 2015. First report of grapevine red blotch-associated virus in archival grapevine material from Sonoma County, California. Plant Dis. 99:895.

Bahder, B. W., Zalom, F. G., Jayanth, M., and Sudarshana, M. R. 2016. Phylogeny of geminivirus coat protein sequences and digital PCR aid in identifying Spissistilus festinus as a vector of grapevine red blotch-associated virus. Phytopathology 106:1223-1230.

Basso, M. F., da Silva, J. C. F., Fajardo, T. V. M., Fontes, E. P. B., and Zerbini, F. M. 2015. A novel, highly divergent ssDNA virus identified in Brazil infecting apple, pear and grapevine. Virus Res. 210:27-33.

Blanco-Ulate, B., Hopfer, H., Figueroa-Balderas, R., Ye, Z., Rivero, R. M., Albacete, A., Pérez-Alfocea, F., Koyama, R., Anderson, M. M., Smith, R. J., Ebeler, S. E., and Cantu, D. 2017. Red blotch disease alters grape berry development and metabolism by interfering with the transcriptional and hormonal regulation of ripening. J. Exp. Bot. 68:1225-1238.

Bustin, S. A., Benes, V., Garson, J. A., Hellemans, J., Huggett, J., Kubista, M., Mueller, R., Nolan, T., Pfaffl, M. W., Shipley, G. L., Vandesompele, J., and Wittwer, C. T. 2009. The MIQE guidelines: Minimum information for publication of quantitative real-time PCR experiments. Clin. Chem. 55:611-622.

Calvi, B. L. 2011. Effects of Red-Leaf Disease on Cabernet Sauvignon at the Oakville Experimental Vineyard and Mitigation by Harvest Delay and Crop Adjustment. University of California, Davis.

Čepin, U., Gutiérrez-Aguirre, I., Balažic, L., Pompe-Novak, M., Gruden, K., and Ravnikar, M. 2010. A one-step reverse transcription real-time PCR assay for the detection and quantitation of grapevine fanleaf virus. J. Virol. Methods 170: 47-56.

Chooi, K. M., Cohen, D., and Pearson, M. N. 2016. Differential distribution and titre of selected grapevine leafroll-associated virus 3 genetic variants within grapevine rootstocks. Arch. Virol. 161:1371-1375.

Cieniewicz, E. J., Pethybridge, S. J., Gorny, A., Madden, L. V., McLane, H., Perry, K. L., and Fuchs, M. 2017. Spatiotemporal spread of grapevine red blotchassociated virus in a California vineyard. Virus Res. 241:156-162.

Cieniewicz, E. J., Pethybridge, S. J., Loeb, G., Perry, K. L., and Fuchs, M. 2018. Insights into the ecology of grapevine red blotch virus in a diseased vineyard. Phytopathology 108:94-102.

Gambino, G., Perrone, I., and Gribaudo, I. 2008. A rapid and effective method for RNA extraction from different tissues of grapevine and other woody plants. Phytochem. Anal. 19:520-525.

Godoy, C., Miranda, X., and Nishida, K. 2006. Pages 244-245 in: Treehoppers of Tropical America. INBio, Costa Rica.
Krenz, B., Thompson, J. R., Fuchs, M., and Perry, K. L. 2012. Complete genome sequence of a new circular DNA virus from grapevine. J. Virol. 86:7715.

Krenz, B., Thompson, J. R., McLane, H. L., Fuchs, M., and Perry, K. L. 2014 Grapevine red blotch-associated virus is widespread in the United States. Phytopathology 104:1232-1240.

Lim, S., Igori, D., Zhao, F., Moon, J. S., Cho, L. S., and Choi, G. S. 2016. First report of grapevine red blotch-associated virus on grapevine in Korea. Plant Dis. 100:1957

Loconsole, G., Saldarelli, P., Doddapaneni, H., Savino, V., Martelli, G. P., and Saponari, M. 2012. Identification of a single-stranded DNA virus associated with citrus chlorotic dwarf disease, a new member in the family Geminiviridae. Virology 432:162-172.

Ma, Y. X., Navarro, B., Zhang, Z. X., Lu, M. G., Zhou, X. P., Chi, S. Q., Di Serio, F., and Li, S. F. 2015. Identification and molecular characterization of a novel monopartite geminivirus associated with mulberry mosaic dwarf disease. J. Gen. Virol. 96:2421-2434.

Maree, H. J., Almeida, R. P. P., Bester, R., Chooi, K. M., Cohen, D., Dolja, V. V., Fuchs, M. F., Golino, D. A., Jooste, A. E. C., Martelli, G. P., Naidu, R. A., Rowhani, A., Saldarelli, P., and Burger, J. T. 2013. Grapevine leafrollassociated virus 3. Front. Microbiol. 4:82.

Monis, J., and Bestwick, R. K. 1996. Detection and localization of grapevine leafroll associated closteroviruses in greenhouse and tissue culture grown plants. Am. J. Enol. Vitic. 47:199-205.

Osman, F., Golino, D., and Rowhani, A. 2011. The effect of seasonal changes on grapevine leafroll associated viruses' titer and distribution in the vine. (Abstr.) Phytopathology 101:S134.

Perry, K. L., McLane, H., Hyder, M. Z., Dangl, G. S., Thompson, J. R., and Fuchs, M. F. 2016. Grapevine red blotch-associated virus is present in freeliving Vitis spp. proximal to cultivated grapevines. Phytopathology 106: 663-670.

Piepho, H. P., Buchse, A., and Emrich, K. 2003. A hitchhiker's guide to mixed models for randomized experiments. J. Agron. Crop Sci. 189:310-322.

Poojari, S., Lowery, D. T., Rott, M., Schmidt, A. M., and Urbez-Torres, J. R. 2017. Incidence, distribution and genetic diversity of grapevine red blotch virus in British Columbia. Can. J. Plant Pathol. 39:201-211.

Reynard, J.-S., Brodard, J., Dubuis, N., Zufferey, V., Schumpp, O., Schaerer, S., and Gugerli, P. 2018. Grapevine red blotch virus: Absence in Swiss vineyards and analysis of potential detrimental effect on viticultural performance. Plant Dis. 102:651-655

Schmittgen, T. D., and Livak, K. J. 2008. Analyzing real-time PCR data by the comparative $\mathrm{C}_{\mathrm{T}}$ method. Nat. Protoc. 3:1101-1108.

Stewart, S., and Nassuth, A. 2001. RT-PCR based detection of rupestris stem pitting associated virus within field-grown grapevines throughout the year. Plant Dis. 85:617-620.

Sudarshana, M. R., Perry, K. L., and Fuchs, M. F. 2015. Grapevine red blotchassociated virus, an emerging threat to the grapevine industry. Phytopathology 105:1026-1032.

Tsai, C. W., Daugherty, M. P., and Almeida, R. P. P. 2012. Seasonal dynamics and virus translocation of Grapevine leafroll-associated virus 3 in grapevine cultivars. Plant Pathol. 61:977-985.

Yepes, L. M., Cieniewicz, E. J., Krenz, B., McLane, H., Thompson, J. R., Perry, K. L., and Fuchs, M. 2018. Causative role of grapevine red blotch virus in red blotch disease. Phytopathology 108:902-909.

Yuan, J. S., Reed, A., Chen, F., and Stewart, C. N. 2006. Statistical analysis of realtime PCR data. BMC Bioinf. 7:85.

Zhang, Y., Singh, K., Kaur, R., and Qiu, W. P. 2011. Association of a novel DNA virus with the grapevine vein-clearing and vine decline syndrome. Phytopathology 101:1081-1090. 